ISSN: 2637-4676

\title{
Agri-Food Projects in Food Land Belts: Conditions for Success
}

\author{
Antonia D Bousbaine ${ }^{1}$ and Christopher R Bryant ${ }^{2 *}$ \\ ${ }^{1}$ Masters in Geographical Science, Free University of Brussels, and doctoral candidate, University of Liège, Belgium \\ ${ }^{2}$ Adjunct Professor, Geography, University of Montreal and the School of Environmental Design and Rural Development, University of \\ Guelph, Guelph, Ontario, Canada
}

Received: 眥 March 27, 2018; Published: 制April 09, 2018

*Corresponding author: Christopher R Bryant, Geography, University of Montreal, Québec, Canada and School of Environmental Design and Rural Development, University of Guelph, Ontario, Canada

\begin{abstract}
Food Land Belts are becoming more and more developed since the beginning of the new century. Characteristically, they involve a larger number of Agri-food projects linking farm production and farmers on the one hand and citizens, organized in different ways, on the other hand. Using some recent research, this short paper suggests some of the critical conditions for the success of these projects, because it is clear that not all Agri-food projects and their Food Land Belts have been successful.
\end{abstract}

Keywords: Agri-food; Food Land Belts; Conditions for successful Agri-food projects; Short circuits; Citizen involvement; Farmer involvement

\section{Introduction}

While Green Belts go back in several countries principally to the end of the Second World War [1], Food Land Belts are much more recent, particularly from the end of the 20th Century onwards, following various sanitary food crises which led to this desire to relocalize foodstuff. What is interesting about Food Land Belts is that they involve a multitude of Agri-food projects, linking agricultural production directly to the consumers who sought healthy locally produced foodstuff for which the source was known [2]. While on the one hand they certainly help conserve agricultural land and farm activities, on the other hand they provide a means of linking the countryside in peri-urban areas around cities directly to the cities. This connection comes from a) non-farm citizens who are concerned with having access to healthy foodstuffs and who initiate the vast majority of initiatives to relocate the sources of their foodstuffs so that they know the sources of their foodstuffs and their location of production [3] and b) partly from small groups of farmers, both leading to a renewal of the linkages between cities and countryside [4]. However, it is clear that not all projects have been successful while others have been very successful and continue to be successful. What makes the difference? We tackle this issue in the next section as it is very important both for farmers and consumers and this research domain represents a field of research that is becoming increasingly important in several countries around the world.

\section{Conditions for Successful Projects}

Figure 1 contains some of the factors or conditions needed to ensure that the various Agri-food projects are successful in making the linkage between farmers and consumers and are successful both from the farmers' perspectives and from the consumers' perspectives. It is based on our understanding of the situation in the research we have undertaken around Liège, Belgium [5] and Montréal, Canada [6,7]. First, it is important to emphasize that each territory (peri-urban area) can be very different, and what works well in one territory may not work well in another. For example, we can invoke the situation in Belgium in two cities, Liège and Charleroi, where people have tried to establish a food belt; in Liège we noted a very dynamic and successful situation but this result is not the same in Charleroi. One characteristic that seems to be generic is that the creation of a Food Belt and its projects is preferably not the result of a 'top down' process which has often led to negative results 
[8]. This does not mean that at some point an overall organization should not be put in place (as with the Montreal Food System), but the desired emphasis is still that the specific projects should be the result of farmers and/or consumers working together (and especially consumers).

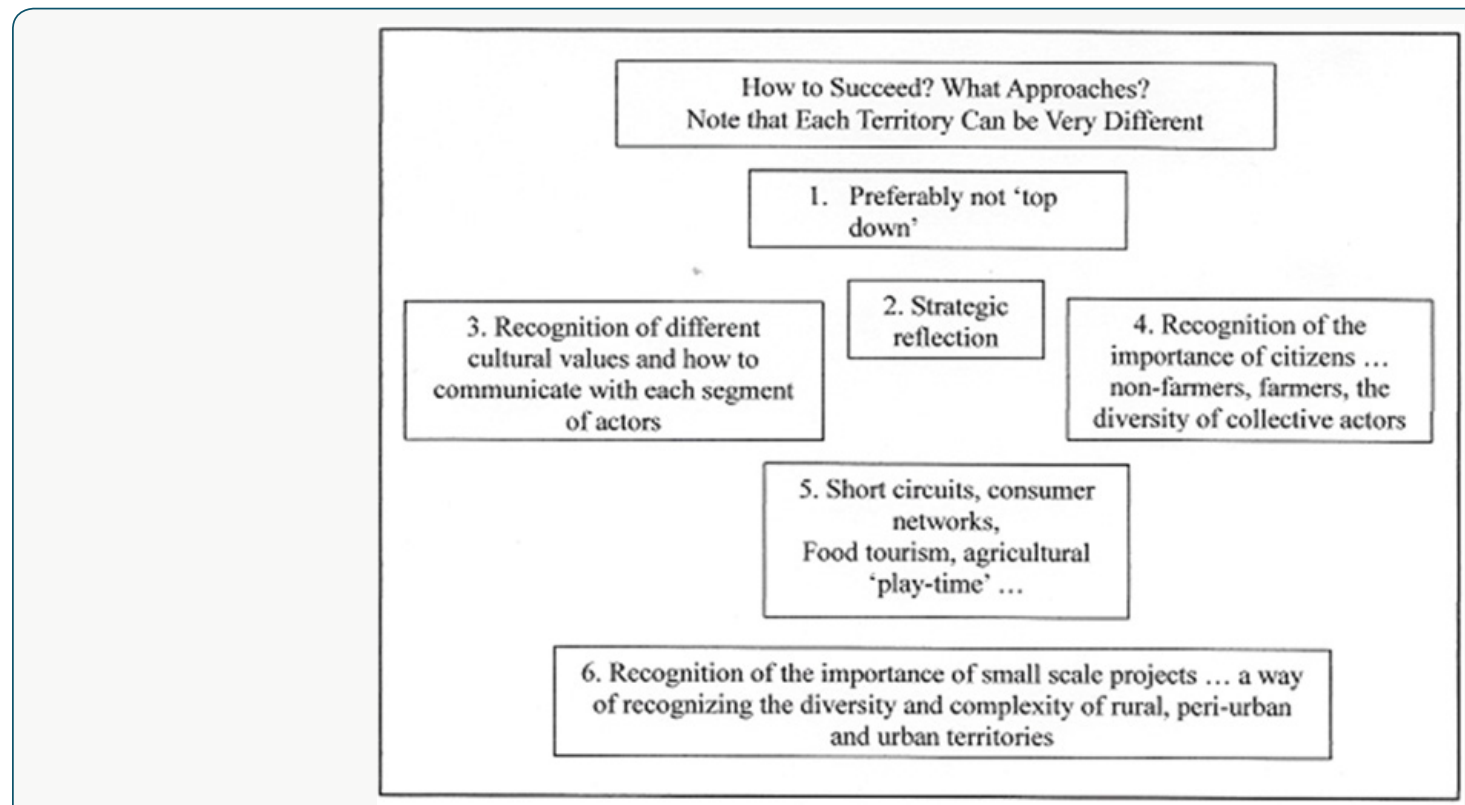

Figure 1: Important Characteristics of a Successful Agri-food Project.

Source: Translated and modified from Bryant (2018).

Second, success at the project scale and the territorial scale is often linked to some form of strategic reflection, and some territories are already using strategic development planning for agricultural development (e.g. in the province of Québec, Canada, in the Regional Municipal Counties) [9]. Note that while these initiatives necessitate a 'bottom-up' approach, governments still have a fundamental role to play - for instance, the Food Policy Councils that have been developed in certain large North American cities (e.g. Toronto, New-York, Knoxville) as well as in Europe (e.g. Malmö, Gand, Bristol, Londres) [10]. Third, given the role of citizens, paying attention to differences in cultural values, it is important both at the specific project scale as well as at the territorial scale to be able to understand how to communicate with different segments of the actors. Fourth, the actors involve citizens, both non-farmers and farmers, and the broad range of different types of collective actors interested in what foodstuffs are produced and how they are sold to the different segments of the consumer market.

Fifth, projects frequently involve Short circuits linking networks of consumers to one or more farm production operations. These can also be linked to consumer networks, some of which can be very informal while others can be quite formal. Sometimes, although more rarely, success comes from providing other opportunities for consumers on the farms, such as 'food tourism' whereby the farm provides opportunities for consumers to see how the food produce can be prepared and as well providing opportunities for families to come and visit a farm which provides a small scale 'zoo of farm animals', as well as wagon rides around the farm including through orchards where these exist. It is like providing 'play-time' activities for families including their children. This reflects Agri-tourism development. Sixth and finally, it is worth emphasizing that most of the projects are indeed relatively small in scale, and while this is not necessarily planned for, in effect this encourages the multiplication of projects that recognize the diversity and complexity of the territories surrounding the cities, such as Liège and Montréal.

\section{Conclusion}

Agri-food projects around cities are developing quite rapidly principally since 2009 , and they contribute to reinforcing the relationships between rural and peril-urban territories around cities where Food Land Belts have been implemented [11]. Based upon our research experience on agriculture around cities, these Food Land Belts are based on numerous small-scale projects for the most part and the Food Land Belts are successful directly based on the success of the small scale Agri-food projects. Their success depends essentially upon the people involved and not just the technologies used on the farms in these projects. Thus, one of the critical aspects of constructive research in this domain is to understand the priorities and values of the people involved ... both the farmers and the consumers, as well as the people engaged in the various collective organizations (municipalities, regions, social organizations). Success is not just based on the technologies that produce healthy food produce, but also on the priorities of the people involved in the various small scale Agri-food projects. Researchers thus must be able to combine both an understanding of the production processes on the farms, the priorities of local farmers, 'local' consumers, elected officials and local development 
officers, as well as being able to mobilize experts regarding healthy agricultural produce.

\section{References}

1. Bryant CR, Russwurm LH, McLellan AG (1982) The City's Countryside: Land and its Management in the Rural Urban Fringe. Longman, London, pp. 249.

2. Morgan K, and Mardse, T, Murdoch J (2006) Worlds of food. Place, power and provenance in the food chain Oxford University Press, India.

3. Ilbery B, Kneafsey M (1998) Product and place: promoting quality products and services in the lagging regions of the European Union. European Urban and Regional Studies 5(4): 329-341.

4. Rouget N (2008) Agricultural dynamics in urban and peri-urban areas. Diversification and adaptation strategies of agriculture. The cases of the southeastern peripheries of Lille and north of Lens. Doctoral Thesis University of Paris, France, pp. 462.

5. Bousbaine AD, Bryant CR (2017) Innovative food systems, case study: the Food Land Belts Liège Land Belgeo: Belgian. Review of Geography (4): 1-19.

6. Bryant CR, Chahine G (2015) Action research and reducing the vulnerability of peri-urban agriculture: a case study from the Montreal Region. Geographical Research.
7. Bryant CR, Bousbaine AD, Akkari C (2018) Strategic Planning for Development and Conservation and the Roles of Citizens. Int J Avian \& Wildlife Biol 3(1).

8. Bryant CR, Akkari C, Bousbaine AD, Delusca K, Daouda O, et al. (2017) The Unintended Negative Consequences of Government Actions and Initiatives in Selected Environmental, Social and Economic Domains: Opportunities for Co-construction Approaches. Journal of Settlements and Spatial Planning pp. 79-88.

9. Bousbaine AD, Akkari C, Bryant CR (2017) Strategic Development Planning for Agricultural Development and the Integration of other Domains Important for the Territory. International Journal of Avian \& Wildlife Biology 2(6).

10. Brand C (2015) Food and metropolisation: rethinking the territory in the light of a forgotten vital issue. Ph.D. Thesis University Grenoble Alpes, France, pp. 656.

11. Bryant CR (2018) The Montreal Food System. Invited presentation at the Round Table: The Agri-urban territories, factors of attractiveness of the big cities: Paris ile de France, Geneva, Milan, Montreal.
This work is licensed under Creative Commons Attribution 4.0 License

To Submit Your Article Click Here: Submit Article

DOI: $10.32474 /$ CIACR.2018.02.000126

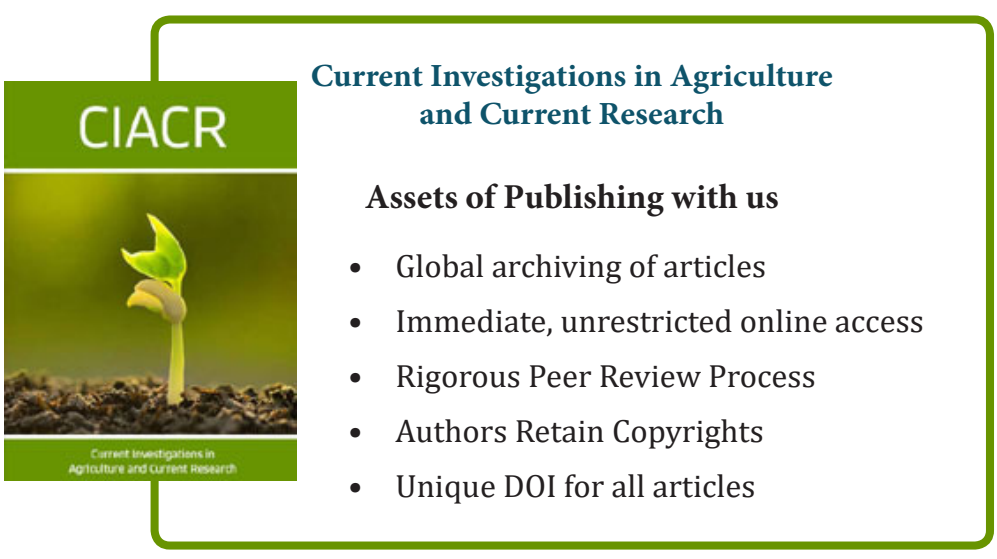

